\title{
金属熱還元法による太陽電池用高純度シリコンの 製造プロセス
}

\section{安田幸司* 岡部 徹}

\author{
東京大学生産技術研究所
}

J. Japan Inst. Metals, Vol. 74, No. 1 (2010), pp. 1-9

(C) 2010 The Japan Institute of Metals

OVERVIEW

\section{Production Processes of Solar Grade Silicon Based on Metallothermic Reduction}

\author{
Kouji Yasuda* and Toru H. Okabe
}

Institute of Industrial Science, the University of Tokyo, Tokyo 153-8505

High purity silicon used for photovoltaic application, namely solar grade silicon ( $\mathrm{SOG}-\mathrm{Si}$ ), has been commercially supplied mainly from the off-grade high purity silicon manufactured by the Siemens process. However, recent and rapid growth in solar cell production induces a serious shortage of SOG-Si. With an aim of resolving low productivity of the Siemens process, various types of SOG-Si production/purification processes have been invented as a post-Siemens process. Some processes are currently under development aiming at establishment of commercial process. These processes can be classified into the following three technologies: (1) decomposition and/or hydrogen reduction of silane gases by improving the current commercial Siemens-based processes, (2) metallothermic reduction of silicon halide compounds by zinc or aluminum, and (3) upgrading metallurgical-grade silicon by employing metallurgical purification methods.

This paper reviews the features of the SOG-Si production processes, particularly the processes based on the metallothermic reduction. These metallothermic reduction processes are classified from the viewpoint of the reductant types and silicon compounds. The future prospect for the development of new high purity silicon production process is presented.

(Received July 23, 2009; Accepted August 26, 2009)

Keywords: high purity silicon, solar cells, polycrystalline silicon, smelting, reduction process, metallothermic reduction

1. は じめに

現在，新エネルギーとして導入が進められている太陽電池 であるが，2006 年から 2008 年にかけて，原料として用い る太陽電池用 $\mathrm{Si}$ (SOG-Si; Solar Grade Silicon, $6 \mathrm{~N}$ 純度)の供 給が不足する事態に陥った. 現在は需給バランスがやや落ち 着いた感があるものの，長期的には原料となる高純度 $\mathrm{Si}$ が 再び不足すると予想されている．そのため，現在法の Siemens 法1,2)に代わる, 太陽電池用 $\mathrm{Si}$ を高い生産性で製造 できる新製錬プロセスの開発が活発に進められている.

現在の技術で確実に目的の不純物を除去して $\mathrm{Si}$ の純度を 上げる方法としては，Si を高い分離能・精製能を有する $\mathrm{Si}$ 化合物へと一旦転化した後に，その化合物を精製してから再 び Siへと還元する方法がある. 現行の高純度 $\mathrm{Si}$ の主たる製 造法である Siemens 法の場合も，精製能が高い化合物を高 純度化する手法を利用して $\mathrm{Si}$ 中の不純物の除去が行われて いる.この種のプロセスにおいては, 精製された超高純度シ リコン化合物を原料として用い，これを高い純度の還元剂を 用いて還元して高純度 $\mathrm{Si}$ を製造する必要がある.

Fig. 1 は，過去に検討された代表的なプロセスに拈ける，

(Present address: Osaka Titanium Technologies Co., Ltd.)

Feed Reductant

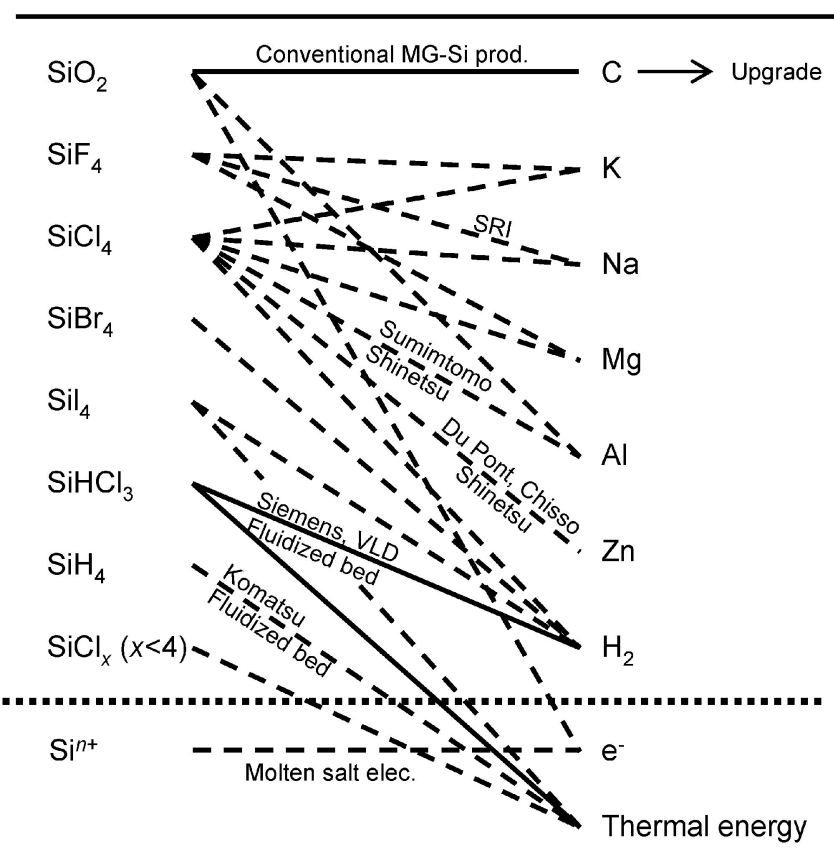

Fig. 1 Relationship between the feed and reductant in the production process of solar grade silicon ${ }^{3}$. 
(a)

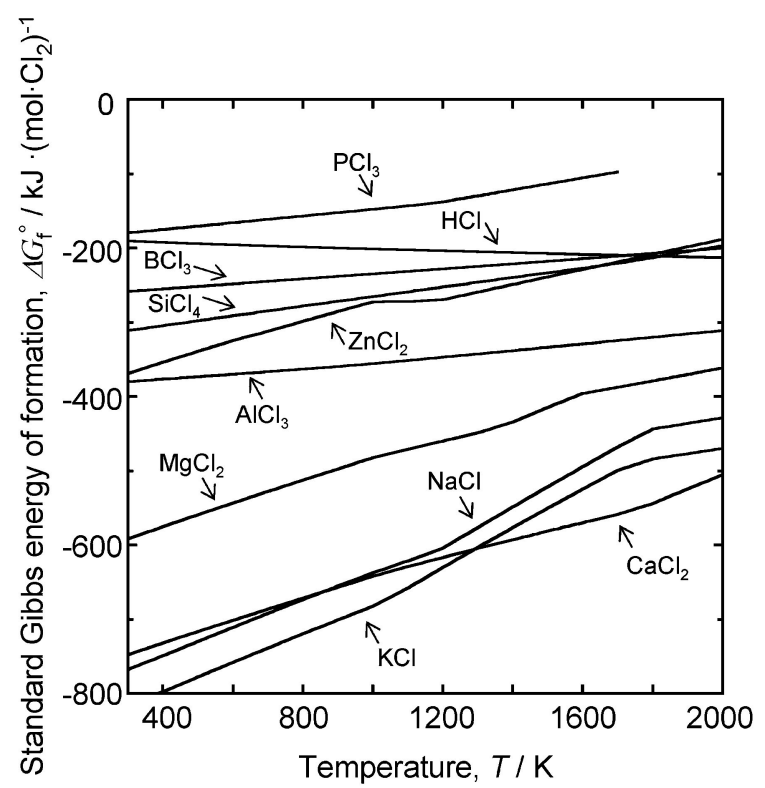

(b)

Temperature, $T / \mathrm{K}$

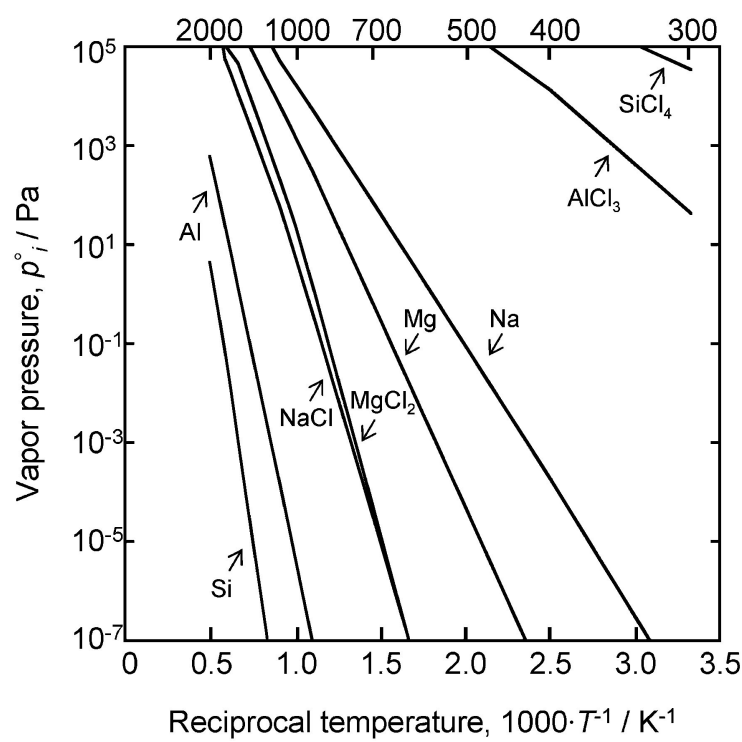

Fig. 2 (a) Ellingham diagram for several chlorides for $\mathrm{Si}$ production $^{3,4)}$. (b) Vapor pressure of selected metals and chlorides $^{3,4)}$.

シリコン化合物と還元剤の関係を整理した図である3). 図で は $\mathrm{SiO}_{2}$ を除き, 上にあるシリコン化合物ほど熱力学的に安 定であり還元が難しい化学種を表記している，また，炭素を 除く還元剤については，図中の上にあるものほど還元力の大 きいものを並べている. シリコン化合物としては, ハロゲン 化物, 水素化物, 水素ハロゲン化物などの精製が容易な化合 物が用いられる. Fig. 2(a)に示す塩化物系のエリンガム図 からもわかるように 較べて比較的還元が容易な化合物であり, 様々な還元剤が利 用可能である。 また, 還元剤は固体, 液体, 気体のいずれの 状態でも供給が行われる一方で, Fig. 2(b) からもわかるよ うにシリコンのハロゲン化物などは蒸気圧が高いため3,4), (a)

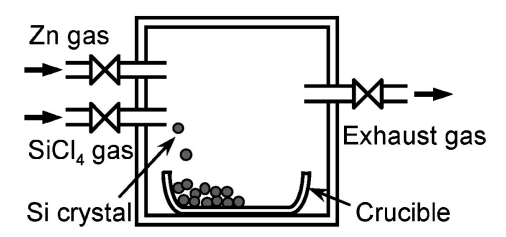

(b)

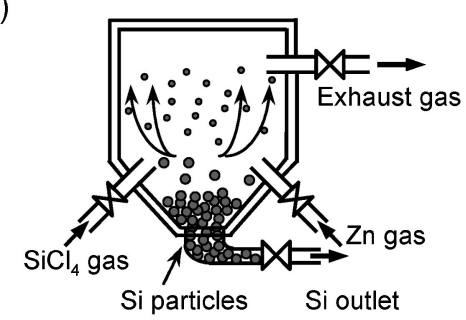

(c)

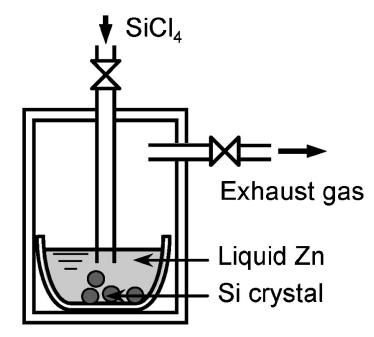

(d)

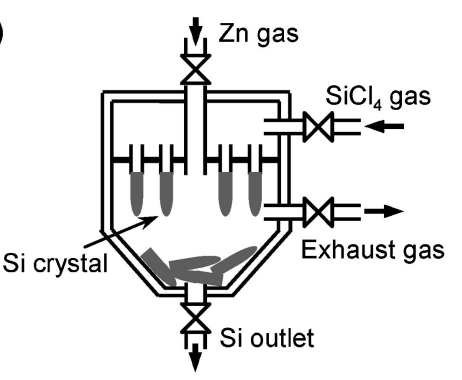

(e)

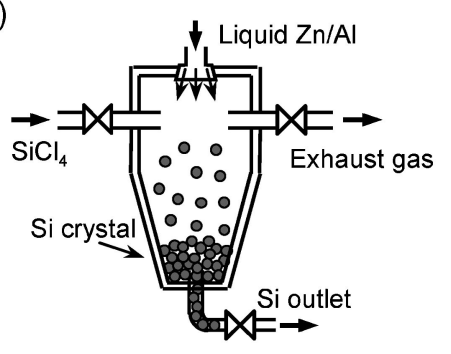

Fig. 3 Comparison of the several polycrystalline Si production processes utilizing the zincothermic reduction of $\mathrm{SiCl}_{4}$. The processes were developed by (a) DuPont ${ }^{5-8)}$, (b) Battelle Columbus Laboratories ${ }^{11,12)}$, (c) Sumitomo $\mathrm{Sitix}^{13)}$, (d) Chisso $^{16)}$, and (e) Shinetsu Chemicals ${ }^{17)}$.

還元時にはこれらのシリコン原料はガスの状態で用いられる. 本稿では，過去に行われてきた種々の $\mathrm{Si}$ 製造プロセスと それらの特徵を, 金属熱還元法を中心に紹介する. Fig. 1 に 示したように金属熱還元法としては，これまでに，亜鉛 $(\mathrm{Zn})$, アルミニウム $(\mathrm{Al})$, アルカリ金属であるナトリウム $(\mathrm{Na})$ やカリウム $(\mathrm{K})$, アルカリ土類金属であるマグネシウ ム $(\mathrm{Mg})$ などを還元剤として用いたプロセスが検討されてお り，本稿ではそれらを還元剤ごとに整理して紹介する。なお， Siemens 法やこれを発展させた手法, 水素還元や熱分解を利 
Table 1 Silicon production processes based on the zincothermic reduction or aluminothermic reduction proposed or investigated in the past.

\begin{tabular}{|c|c|c|}
\hline Name/Reference & Chemical reaction/Temperature/Note & Shape of products \\
\hline \multicolumn{3}{|c|}{ Zincothermic reduction of $\mathrm{SiCl}_{4}$} \\
\hline DuPont Process/Lyon et al. ${ }^{5)}$ & $\begin{array}{l}\mathrm{SiCl}_{4}(\mathrm{~g})+2 \mathrm{Zn}(\mathrm{g}) \rightarrow \mathrm{Si}(\mathrm{s})+2 \mathrm{ZnCl}_{2}(\mathrm{~g}) / 1223 \mathrm{~K} / \text { Batch-type process, Si with } 99.97 \% \\
\text { purity was obtained. }\end{array}$ & Fiber \\
\hline DuPont Process/Bertrand ${ }^{6-8}$ & $\begin{array}{l}\mathrm{SiCl}_{4}(\mathrm{~g})+2 \mathrm{Zn}(\mathrm{g}) \rightarrow \mathrm{Si}(\mathrm{s})+2 \mathrm{ZnCl}_{2}(\mathrm{~g}) / 1173-1523 \mathrm{~K} / \text { Continuous process, fluidized bed } \\
\text { reaction, Si with } 99.9+\% \text { purity was obtained. }\end{array}$ & Powder \\
\hline Not provided/Johnson and Amick ${ }^{9)}$ & $\mathrm{SiCl}_{4}(\mathrm{~g})+2 \mathrm{Zn}(\mathrm{g}) \rightarrow \mathrm{Si}(\mathrm{s})+2 \mathrm{ZnCl}_{2}(\mathrm{~g}) / 1073-1273 \mathrm{~K} / \mathrm{SiCl}_{4}$ was diluted with carrier gas. & Fiber \\
\hline $\begin{array}{l}\text { Battelle Columbus Laboratories/ } \\
\text { Browning } \text { et al. }{ }^{11,12)}\end{array}$ & $\begin{array}{l}\mathrm{SiCl}_{4}(\mathrm{~g})+2 \mathrm{Zn}(\mathrm{g}) \rightarrow \mathrm{Si}(\mathrm{s})+2 \mathrm{ZnCl}_{2}(\mathrm{~g}) / 1100-1300 \mathrm{~K} / \mathrm{Semi}^{-c o n t i n u o u s ~ p r o c e s s} \text {, fluidized } \\
\text { bed reaction, } \mathrm{ZnCl}_{2} \text { was electrolyzed into } \mathrm{Zn} \text { and } \mathrm{Cl}_{2} \text { in } \mathrm{ZnCl}{ }_{2}-\mathrm{KCl} \text { molten salt. }\end{array}$ & Powder \\
\hline Sumitomo Sitix/Natume et al. ${ }^{13)}$ & $\mathrm{SiCl}_{4}(\mathrm{~g})+2 \mathrm{Zn}(\mathrm{l}) \rightarrow \mathrm{Si}(\mathrm{s})+2 \mathrm{ZnCl}_{2}(\mathrm{~g}) /-1073 \mathrm{~K} / \mathrm{ZnCl}_{2}$ was electrolyzed into $\mathrm{Zn}$ and $\mathrm{Cl}_{2}$. & Deposit \\
\hline $\begin{array}{l}\text { Not provided/Shimamune and } \\
\text { Yoshikawa14) }\end{array}$ & $\begin{array}{l}\mathrm{SiCl}_{4}(\mathrm{~g})+2 \mathrm{Zn}(\mathrm{g}) \rightarrow \mathrm{Si}(\mathrm{s})+2 \mathrm{ZnCl}_{2}(\mathrm{~g}) / 1183-1473 \mathrm{~K} / \text { Reaction occurred on the Si seed } \\
\text { crystal. }\end{array}$ & Epitaxial deposit \\
\hline Umicore Belg/Robert and Zijlema ${ }^{15)}$ & $\begin{array}{l}\mathrm{SiCl}_{4}(\mathrm{~g})+2 \mathrm{Zn}(1) \rightarrow \mathrm{Si}(\mathrm{s})+2 \mathrm{ZnCl}_{2}(\mathrm{~g}) / 1005-1180 \mathrm{~K} / \text { Produced } \mathrm{Si} \text { was purified at a } \\
\text { temperature above the melting point of } \mathrm{Zn} \text {. }\end{array}$ & Deposit \\
\hline $\begin{array}{l}\text { Chisso (Japan Solar Silicon)/Honda } \\
\text { et al. }{ }^{16)}\end{array}$ & $\mathrm{SiCl}_{4}(\mathrm{~g})+2 \mathrm{Zn}(\mathrm{g}) \rightarrow \mathrm{Si}(\mathrm{s})+2 \mathrm{ZnCl}_{2}(\mathrm{~g}) / 1073-1473 \mathrm{~K} /$ Continuous production & Fiber \\
\hline Shinetsu Chemicals/Sakaguchi ${ }^{17)}$ & $\mathrm{SiCl}_{4}(\mathrm{~g})+2 \mathrm{Zn}(\mathrm{l}, \mathrm{g}) \rightarrow \mathrm{Si}(\mathrm{s})+2 \mathrm{ZnCl}_{2}(\mathrm{~g}) / 1073 \mathrm{~K}-/ \mathrm{Zn}$ was supplied as fine particles. & Deposit \\
\hline \multicolumn{3}{|c|}{ Aluminothermic reduction of $\mathrm{SiCl}_{4}$} \\
\hline Not provided/Weaver ${ }^{18)}$ & $\begin{array}{l}3 \mathrm{SiCl}_{4}(\mathrm{~g})+4 \mathrm{Al}(\mathrm{l}) \rightarrow 3 \mathrm{Si}(\mathrm{s})+4 \mathrm{AlCl}_{3}(\mathrm{~g}) / 1173-1473 \mathrm{~K} / \text { Property of produced Si was not } \\
\text { provided. }\end{array}$ & Not provided \\
\hline Not provided/Yoshizawa et al. ${ }^{19)}$ & $\begin{array}{l}3 \mathrm{SiCl}_{4}(\mathrm{~g})+4 \mathrm{Al}(\mathrm{l}) \rightarrow 3 \mathrm{Si}(\mathrm{s})+4 \mathrm{AlCl}_{3}(\mathrm{~g}) / 1023-1273 \mathrm{~K} / \mathrm{Si} \text { with } 99.9 \% \text { purity was } \\
\text { obtained. }\end{array}$ & $\begin{array}{l}\text { Powder, Fiber, } \\
\text { Dendrite }\end{array}$ \\
\hline Toth Aluminum Corp./Terry et al. ${ }^{20)}$ & $\begin{array}{l}3 \mathrm{SiCl}_{4}(1, \mathrm{~g})+4 \mathrm{Al}(\mathrm{s}) \rightarrow 3 \mathrm{Si}(\mathrm{s})+4 \mathrm{AlCl}_{3}(1, \mathrm{~g}) / 200-850 \mathrm{~K} / \text { Solid } \mathrm{Al} \text { was used as a } \\
\text { reductant. }\end{array}$ & Not provided \\
\hline Bayer AG/Woditsch et al. ${ }^{21)}$ & $\begin{array}{l}3 \mathrm{SiCl}_{4}(\mathrm{~g})+4 \mathrm{Al}(\mathrm{s}) \rightarrow 3 \mathrm{Si}(\mathrm{s})+4 \mathrm{AlCl}_{3}(\mathrm{~g}) / 823-923 \mathrm{~K} / \mathrm{AlCl}_{3} \text { was electrolyzed into } \mathrm{Al} \text { and } \\
\mathrm{Cl}_{2} .\end{array}$ & Cake \\
\hline $\begin{array}{l}\text { Sumitomo Chemicals/Saegusa and } \\
\text { Yamabayashi22) }\end{array}$ & $\begin{array}{l}3 \mathrm{SiCl}_{4}(\mathrm{~g})+4 \mathrm{Al}(\mathrm{l}) \rightarrow 3 \mathrm{Si}(\mathrm{s})+4 \mathrm{AlCl}_{3}(\mathrm{~g}) / 673-1473 \mathrm{~K} / \mathrm{AlCl}_{3} \text { was electrolyzed into } \mathrm{Al} \text { and } \\
\mathrm{Cl}_{2} .\end{array}$ & Deposit \\
\hline
\end{tabular}

用する高純度 $\mathrm{Si}$ の製造法については，別報3を参照された い.さらに，現在検討が行われている新規プロセスを原理か ら再検討することで，太陽電池用 $\mathrm{Si}$ の製造プロセスの将来 像の模索を試みる。

\section{2. ハロゲン化シリコンの亜鉛還元}

金属熱還元法による高純度 $\mathrm{Si}$ の製造は，他の製造法と比 べて, 歴史的に最も古くから行われている. 特に, 以下の反 応式で示される $\mathrm{SiCl}_{4}$ の $\mathrm{Zn}$ 熱還元法による $\mathrm{Si}$ 製造法は, Siemens 法以前の工業的な高純度 $\mathrm{Si}$ 製造法であり，広く開 発が行われた。

$$
\mathrm{SiCl}_{4}(\mathrm{~g})+2 \mathrm{Zn}(\mathrm{l}, \mathrm{g}) \rightarrow \mathrm{Si}(\mathrm{s})+2 \mathrm{ZnCl}_{2}(\mathrm{~g})
$$

過去に行われた， $Z n$ 還元による高純度 $\mathrm{Si}$ 製造法を Table 1 にまとめ, 代表的なプロセスの原理を Fig. 3 に示す5-17).

初期の $\mathrm{Zn}$ 還元法は DuPont 社により開発され，1951 年に は工業的製造が開始された ${ }^{5-8)}$. Fig. 4 にフロー図を示す DuPont 法では, $950^{\circ} \mathrm{C}$ において $\mathrm{SiCl}_{4}$ ガスと $\mathrm{Zn}$ ガスを反応 させることにより, 高純度 $\mathrm{Si}$ の製造を行う. 還元剤の $\mathrm{Zn}$ は Si との化学的親和性が小さいためケイ化物を作らな い23). また， $\mathrm{Zn}$ と副生成物の塩化亜鉛 $\left(\mathrm{ZnCl}_{2}\right)$ の高温におけ る蒸気圧が高く, 反応温度において $\mathrm{Zn}$ を含む化学種は全て 気相として存在する. そのため, 反応後の $\mathrm{Zn}$ 抢よび $\mathrm{ZnCl}_{2}$ は容易に揮散させて除去することができる，さらに，当時で

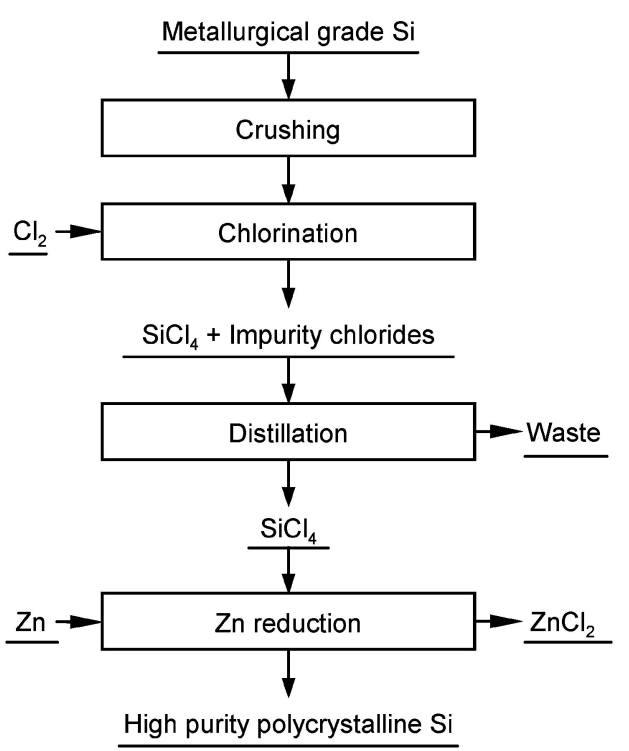

Fig. 4 Process flow chart for the DuPont process ${ }^{5-8)}$.

も蒸留法などにより $5 \mathrm{~N}$ 純度の $\mathrm{Zn}$ の製造が可能であったた め, 高純度 $\mathrm{Si}$ を得ることが可能であった. しかし, Znの還 元力が強く, $\mathrm{SiCl}_{4}$ のみならず不純物の三塩化ホウ素 $\left(\mathrm{BCl}_{3}\right)$ も同時にホウ素へと還元されるため, DuPont 法では反応系 内に B が混入すると生成 $\mathrm{Si}$ に混入する問題がある。 また, 
Si $1 \mathrm{~kg}$ を得るために $\mathrm{Zn}$ を $4.65 \mathrm{~kg}$ も必要とするため, DuPont 法では大量の $\mathrm{ZnCl}_{2}$ が副生成物として発生する。 $\mathrm{Zn}$ 熱還元法を大型プロセスとして利用する場合, $\mathrm{ZnCl}_{2}$ の循環 利用は重要な課題である.さらに，1950 年代の技術水準で は，高純度の反応気体を輸送する技術にも困難があり，高い 機密性が要求される大型反応装置を長期間, 連続的に運用す る上で種々の障害が残っていた。このため，後に開発された Siemens 法に押される形で 1962 年に商業的製造を中止した.

1970 年代から 1980 年代初頭にかけて， Battelle Columbus Laboratories では, $\mathrm{SiCl}_{4}$ の $\mathrm{Zn}$ 還元に流動床を用 いる(半)連続製造法が工業的プロセスを視野として研究され た11,12).この手法では，DuPont 法とは異なり，Fig. 5 に示 すような $\mathrm{ZnCl}_{2}$ を循環利用するクローズドサイクルが提唱さ れ，主な工程は塩化工程，精製工程，還元工程，電解工程の 4 つから成っている。還元工程に抢ける副生成物の $\mathrm{ZnCl}_{2}$ は 回収され，電解後に $\mathrm{Zn}$ は還元工程へ， $\mathrm{Cl}_{2}$ は塩化工程へ々 リサイクルされる. 副生成物の $\mathrm{ZnCl}_{2}$ を廃棄あるいは外販す る必要が無いだけでなく, 電解工程で再生される $\mathrm{Zn} の$ 純度 を高いレベルに維持できるため，生成する $\mathrm{Si} へ の$ 不純物の 混入を少なく抑えられるといった長所がある。クローズドサ イクルを用いた $\mathrm{SiCl}_{4}$ の $\mathrm{Zn}$ 還元による $\mathrm{Si}$ 製造法は， 1999 年に住友シチックスからも特許が出願されている13)。

$\mathrm{Zn}$ 還元法による析出物の形状は, 繊維状の $\mathrm{Si}$ が得られる と過去に多く報告されているが5,9,16)，Si の種結晶を用いる とエピタキシャル状に成長させることができるとの特許も存 在する ${ }^{14)}$. 近年では，チッソが新日鉱ホールディングスや 東邦チタ二ウムと協力して, $\mathrm{SiCl}_{4}$ の $\mathrm{Zn}$ 還元による太陽電 池級 Si の製造法を開発し，2010 年度より工業的製造を開始 する予定との報告もあり，注目を集めている ${ }^{16,24)}$. 他にも， いくつかの企業が Zn 熱還元法による高純度 $\mathrm{Si}$ の製造を試 みているようであるが，詳細は明らかではない，Zn 熱還元 法は，Znの循環利用とその純度管理，さらには得られる $\mathrm{Si}$ の純度や析出形態, エネルギー効率の問題が解決されれば,

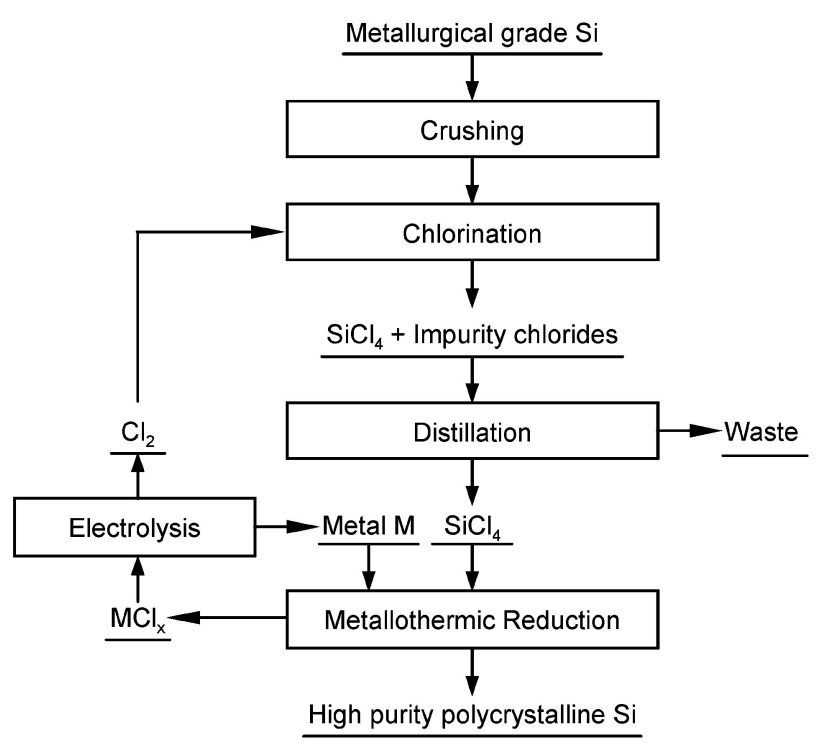

Fig. 5 Process flow chart for the silicon production by metallothermic reduction of $\mathrm{SiCl}_{4}$.
大型の量産プロセスとして発展する可能性が大きい。

\section{3. ハロゲン化シリコンのアルミニウム還元}

$\mathrm{SiCl}_{4}$ の $\mathrm{Al}$ 還元による高純度 $\mathrm{Si}$ 製造法も，現在までに多 くの研究がなされており，代表的なものを Table 1 にまとめ て示す17-22). $\mathrm{Al}$ も $\mathrm{Si}$ との化学的親和性が小さい元素であ り，ケイ化物を作ることは無い23)。しかし，Alの蒸気圧は $1300 \mathrm{~K}$ でも $10^{-7} \mathrm{~atm}$ と低く4)，還元剂に $\mathrm{Al}$ を用いる場合 は前述の $\mathrm{Zn}$ の場合と異なり，気相で $\mathrm{Al}$ の供給を行うこと ができない。このため，還元剤の $\mathrm{Al}$ は固体もしくは液体の 形で供給される。一方，副生成物の塩化アルミニウム $\left(\mathrm{AlCl}_{3}\right)$ は蒸気圧が高いため気体として除去される.

$$
3 \mathrm{SiCl}_{4}(\mathrm{~g})+4 \mathrm{Al}(\mathrm{s}, 1) \rightarrow 3 \mathrm{Si}(\mathrm{s})+4 \mathrm{AlCl}_{3}(\mathrm{~g})
$$

過去の代表的な報告に抢けるプロセス図を Fig. 6 にまとめ て示す．1961 年の吉沢らの報告によると，生成する $\mathrm{Si}$ の形

(a)

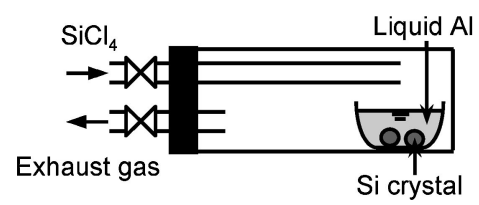

(b)

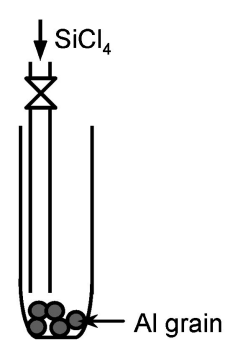

(c)

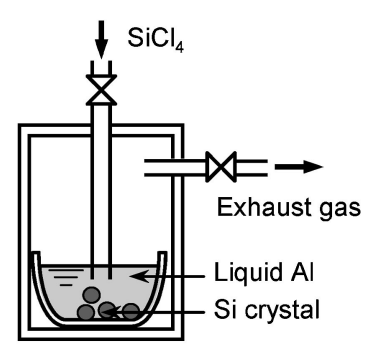

(d)

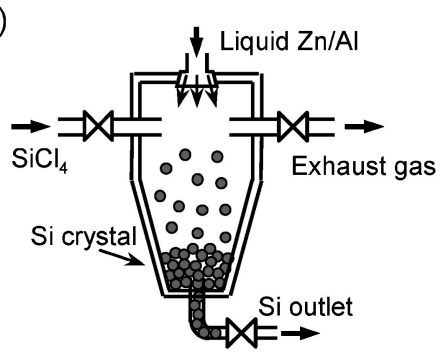

Fig. 6 Comparison of the several polycrystalline Si production processes utilizing the aluminothermic reduction of $\mathrm{SiCl}_{4}$. The processes were developed by (a) Yoshizawa et al. ${ }^{19)}$, (b) Bayer $\mathrm{AG}^{21)}$, (c) Sumitomo Chemicals ${ }^{22)}$, and (d) Shinetsu Chemicals ${ }^{17)}$. 
状は $\mathrm{SiCl}_{4}$ の供給速度により異なり, 粉末状, 樹状, 繊維状 などの形状で得られる ${ }^{19)}$. Zn 還元と同様に, 副生成物の $\mathrm{AlCl}_{3}$ は電気分解によって $\mathrm{Al}$ と塩化㓮の塩素 $\left(\mathrm{Cl}_{2}\right)$ ガスに再 生し循環利用できるため, $\mathrm{Al}$ 熱還元法によるクローズドサ イクルの特許も Bayer 社から出願されている ${ }^{21)}$. 近年で は, 住友化学や信越化学からも, クローズドサイクルによる $\mathrm{SiCl}_{4}$ の $\mathrm{Al}$ 還元の特許が出願されている17,22). $\mathrm{Al}$ を還元剂 に用いた場合には, 反応条件によっては液体の $\mathrm{Si}-\mathrm{Al}$ 合金が 一部生成する可能性がある.しかし, $\mathrm{Si}-\mathrm{Al}$ 合金相からの相 分離により $\mathrm{Si}$ 相が析出する場合には, ホウ素 $(\mathrm{B})$ やリン $(\mathrm{P})$ などの不純物が合金相に残るために純度の高い $\mathrm{Si}$ が得られ るとの報告があり25-27), 不純物の混入に強いプロセスの構 築が可能となる. 太陽電池級 $\mathrm{Si} へ の \mathrm{Al}$ の許容含有量が約 $0.01 \mathrm{ppm}$ 以下であるのに対して ${ }^{28)}$, $\mathrm{Si}$ 中への $\mathrm{Al}$ の固溶量 は温度によって異なるが $100 \mathrm{ppm}$ オーダーと高い。このた め, 還元後に得られた Si は, 偏析法を利用するなどして $\mathrm{Al}$ 含有量の少ない $\mathrm{Si}$ に精製する必要がある. Al 成分の除去法 としては, 複数回の偏析処理, もしくは電子ビーム $(\mathrm{EB}) な$ ぞによる揮発処理が，金属級 Si の精製に用いられてい る29,30). しかし, これらの手法を用いると精製コストが高く なるため, 有効な $\mathrm{Al}$ 除去法の開発が必要となっている.

\section{4. ハロゲン化シリコンのアルカリ金属/アルカリ土 類金属による還元}

代表的な報告を Table 2 にまとめて示すように, 還元剤に $\mathrm{Na}$ や $\mathrm{K}$ などのアルカリ金属や, $\mathrm{Mg}$ などのアルカリ土類金 属を用い，八ロゲン化 $\mathrm{Si}$ を睘元することで $\mathrm{Si}$ を製造する方 法も, 過去に数多く研究されている31-41).

$\mathrm{SiX}_{4}(\mathrm{~g}, \mathrm{X}=\mathrm{F}, \mathrm{Cl}, \mathrm{Br})+\mathrm{M}(\mathrm{l}, \mathrm{g}, \mathrm{M}=\mathrm{Na}, \mathrm{K}, \mathrm{Mg}) \rightarrow \mathrm{Si}(\mathrm{s}, 1)+$ $\mathrm{MX}_{y}(\mathrm{~s}, 1, \mathrm{~g})$
また， 1824 年にスウェーデンの科学者 J. J. Berzelius に より歴史上初めて $\mathrm{Si}$ が単離された際の反応も, アルカリ金 属の 1 つである $\mathrm{K}$ を還元剤として用いた反応であった。 Berzelius は, まず $\mathrm{SiO}_{2}$ とフッ化水素酸 $(\mathrm{HF})$ との反応で得 られた $\mathrm{SiF}_{4}$ を $\mathrm{K}$ と反応させ, 複合フッ化物である珪フッ化 カリウム $\left(\mathrm{K}_{2} \mathrm{SiF}_{6}\right)$ を製造した. 次いで, $\mathrm{K}_{2} \mathrm{SiF}_{6}$ を粒状の $\mathrm{K}$ と混合し試験管中で加熱したところ, Si が還元されケイ化 カリウムが生成した．還元で得られた生成物を水洗すること で，ケイ化カリウム中のカリウムが副生成物のフッ化カリウ ムとともに除去され, Si が単離された ${ }^{42)}$.

$$
\mathrm{K}_{2} \mathrm{SiF}_{6}(\mathrm{~s})+4 \mathrm{~K}(\mathrm{l}) \rightarrow \mathrm{Si}(\mathrm{s})+6 \mathrm{KF}(\mathrm{s})
$$

アルカリ金属やアルカリ土類金属による熱還元法では, 還 元剤の金属は蒸気で供給できるが，一般に反応生成物の塩は 蒸気圧が低く, 液体や固体として析出する条件となることが 多い。したがって, 還元反応後に生成 $\mathrm{Si}$ と反応生成物の塩 との分離を行うには, 水洗いなどの分離操作を行う必要があ る. 中には, Fig. 7 に示すように, プラズマを用いた超高温 中 (約 $2000 \mathrm{~K}$ ) で反応を行い, 副生成物のハライド塩を気相 として除去するという報告もある ${ }^{34-36)}$ 。この場合, 八ライ ド塩は, 乾式法による再生が可能であり, 例えば電解工程に より $\mathrm{Na}$ 金属と $\mathrm{Cl}_{2}$ ガスへと再生して循環利用できる.

四フッ化ケイ素 $\left(\mathrm{SiF}_{4}\right)$ を原料に用いるプロセスとしては, $\mathrm{Na}$ 還元による $\mathrm{Si}$ 製造法が工業化を視野に入れた製造法とし て, 過去に Stanford Research Institute で研究された(Fig. 8) ${ }^{38,39)}$. この際の原料となる $\mathrm{SiF}_{4}$ は, 肥料の副生成物とし て大量に得られる安価な $\mathrm{H}_{2} \mathrm{SiF}_{6}$ から製造される. $\mathrm{SiF}_{4}$ と $\mathrm{Na}$ との反応でも副生成物として固体のフッ化ナトリウム $(\mathrm{NaF})$ が得られるため, Fig. 8(b)にあるように水洗いによ る $\mathrm{Si}$ と塩との分離工程が必要となる。

一般的には, $\mathrm{Na}$ や $\mathrm{K}, \mathrm{Mg}$ などのアルカリ金属やアルカリ 土類金属は $\mathrm{Si}$ との化学的親和力が強く, ケイ化物が存在す

Table 2 Silicon production processes based on the metallothermic reduction of silicon halides by alkali/alkaline earth metals proposed or investigated in the past.

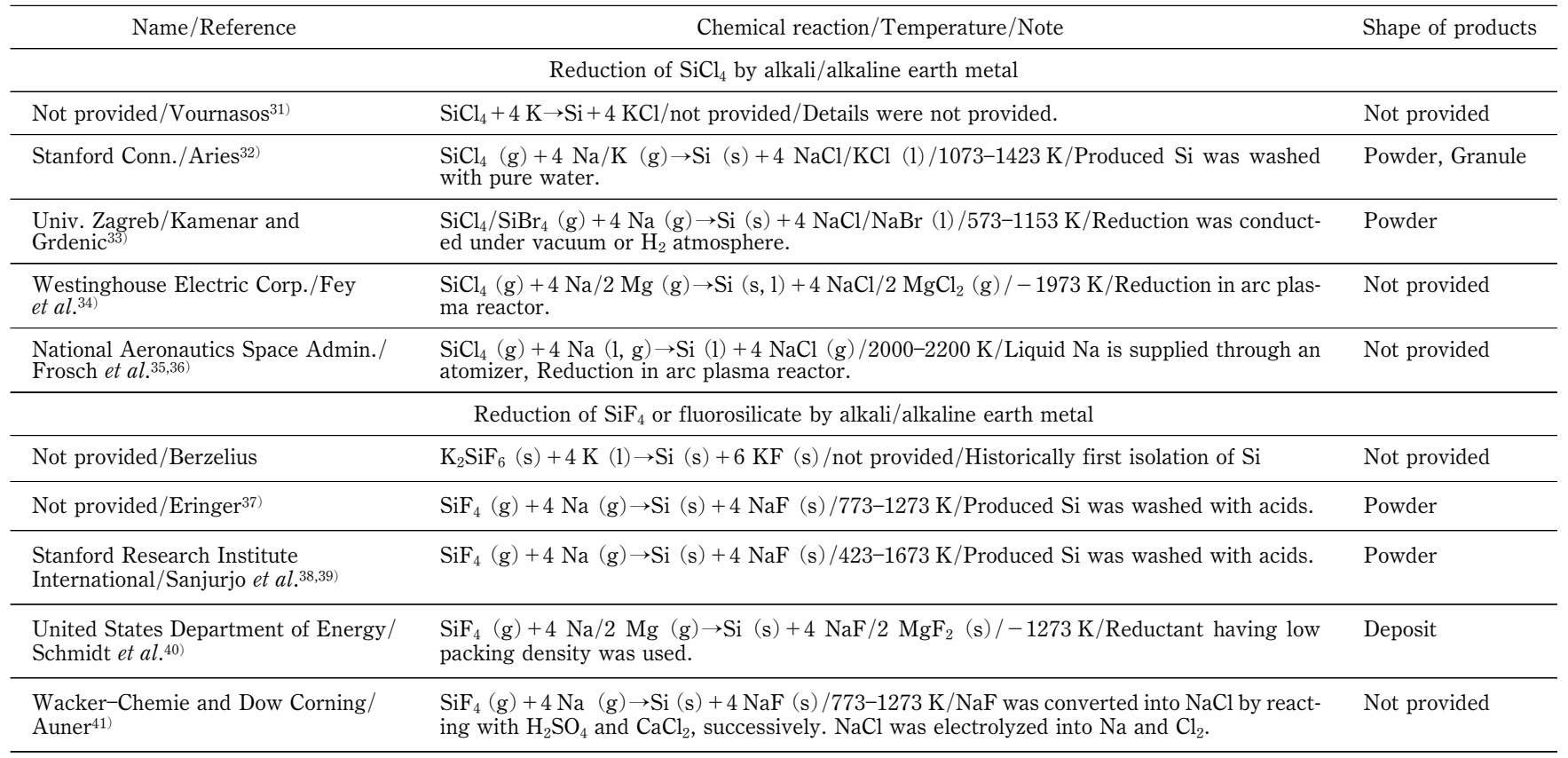




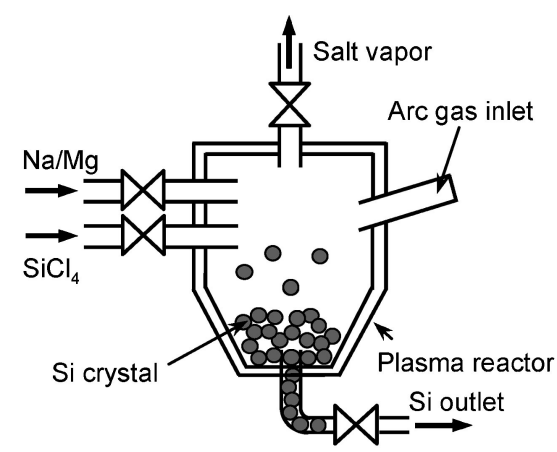

Fig. 7 Schematic illustration of the reactor for polycrystalline $\mathrm{Si}$ production by reduction of $\mathrm{SiCl}_{4}$ by $\mathrm{Na} / \mathrm{Mg}$ liquid/ vapor $^{34-36)}$.

(a)

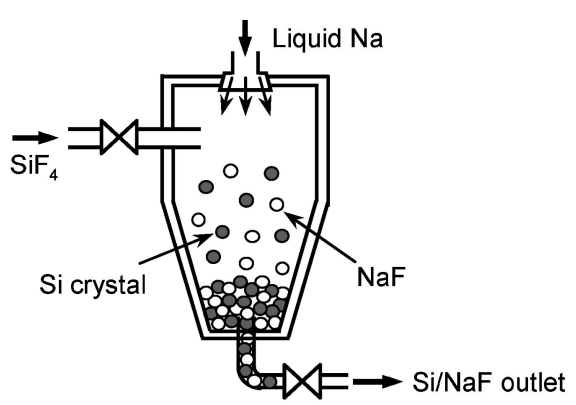

(b)

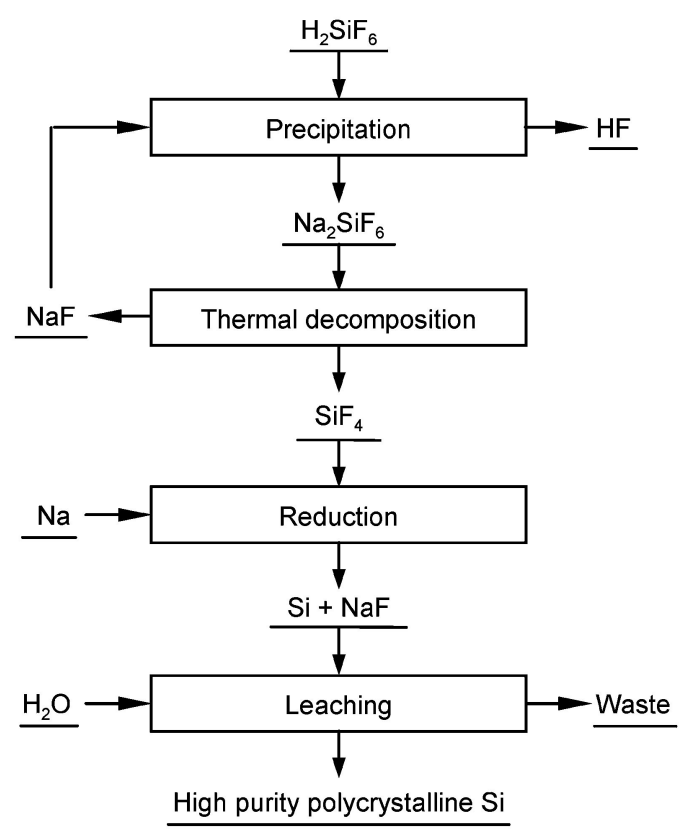

Fig. 8 (a) Schematic illustration of the reactor and (b) process flow chart for polycrystalline Si production by reduction of $\mathrm{SiF}_{4}$ by sodium ${ }^{38,39)}$.

る ${ }^{23)}$ 。このため,これらの金属を還元剂に用いる場合， Si から還元剤を除去する必要がある。特許やVournasos の報 告31)ではケイ化物の生成の有無は不明であるが, 還元剤に $\mathrm{Na}$ を用いた Kamenar ら ${ }^{33)}$ やSanjurjo ら ${ }^{38)}$ の報告では, 生 成物はそれぞれ，Si と塩化ナトリウム $(\mathrm{NaCl})$ の混合物, $\mathrm{Si}$
とフッ化ナトリウム $(\mathrm{NaF})$ の混合物であり, ケイ化物の生成 は確認されなかった。 $\mathrm{Si}-\mathrm{Na}$ 系には, $\mathrm{NaSi}, \mathrm{NaSi}_{2}, \mathrm{Na}_{4} \mathrm{Si}_{23}$, $\mathrm{Na}_{x} \mathrm{Si}_{136}$ といった化合物が存在するにもかかわらず23)，Na 還元による Si 製造法において, これら化合物が生成しなか った理由は不明であるが, 高温における $\mathrm{Na}$ の高い蒸気圧 $(\mathrm{Na}$ の沸点は $1156 \mathrm{~K})$ が要因である可能性がある. 前述の $\mathrm{Zn}$ や $\mathrm{Al}$ による還元法と同様, 還元工程で得られる副産物の 塩を電気分解して再利用し, 高純度のアルカリ金属/アルカ リ土類金属を製造することにより, クローズドサイクルを構 築することが可能である.

\section{5. 金属熱還元法の還元剂別の特徵と各高純度シリコ ン製造プロセスの特徵の比較}

前章までに，過去に行われたシリコン化合物からの Si 製 造法を, 還元剂別に分けて紹介した. 各還元剤を利用した場 合のプロセスの特徵を Table 3 に, さらに各高純度 $\mathrm{Si}$ 製造 法の特徵を Table 4 にまとめた. 高純度 $\mathrm{Si}$ 製造を目的とし たプロセスに扔いては, シリコン化合物を還元する還元剤に は,

（1）高純度の還元剤を容易に製造して利用することができ る

（2）生成 $\mathrm{Si}$ と化合物を作らないもしくは作りにくい （あるいは作ったとしても容易に分離・除去できる）

（3） 反応後に副生成物や過剩の還元剤の分離や除去が容易

（4）反応容器を侵すことがない

（5）安価かつ再生する場合のエネルギーコストが低い などといった条件が求められる.

上に挙げた 5 つの条件を最も満たす還元剤は $\mathrm{H}_{2}$ であり, $\mathrm{SiHCl}_{3}$ や $\mathrm{SiH}_{4}$ の熱分解や $\mathrm{H}_{2}$ 還元を用いた Siemens 法べー スのプロセスは, 確実に高純度の $\mathrm{Si}$ が得られるという点で 優れている. しかし, 前報3)で説明したように, $\mathrm{H}_{2}$ は還元 剂として還元力が弱く, $\mathrm{SiHCl}_{3}$ や $\mathrm{SiH}_{4}$ などの熱分解や $\mathrm{H}_{2}$ を用いた反応は $\mathrm{Si}$ の生成速度が小さいために, 生産性が低 いという久点がある. また, シラン系ガスの製造工程は複雑 な多段階反応を用いたプロセスであり, シラン系ガスの製造 コストも高い. 現在開発中の流動床を用いた $\mathrm{Si}$ 製造法や $\mathrm{Si}$ の溶融析出法は, 反応速度の増加が可能なだけでなく, 装置 下部から (半)連続的に生成 $\mathrm{Si}$ を回収できる.このため,こ れらのプロセスは，(半)連続プロセスとしても構築可能であ り, 高い生産性を達成できる可能性を秘めている．流動床に よる反応は，原理的には分解が容易な $\mathrm{SiH}_{4}$ の熱分解反応と の相性が良いが，コスト的な面を考えると製造コストが高い $\mathrm{SiH}_{4}$ よりは $\mathrm{SiHCl}_{3}$ の方が優れて抢り, 今後は $\mathrm{SiHCl}_{3}$ を用 いた反応が主流になると予想される。

還元剂に $\mathrm{Zn}$ や $\mathrm{Al}$ ，アルカリ金属/アルカリ土類金属を用 いる，ハロゲン化シリコンの金属熱還元による $\mathrm{Si}$ 製造法は, Siemens 法べースのプロセスが利用する $\mathrm{H}_{2}$ 還元や熱分解と 比較して, 還元反応の速度が桁違いに大きく, 量産プロセス を設計する点で生産性を大幅に増大できる点が大きなメリッ トである，さらに，金属熱睘元法による Si 製造法は，例え ば Zn 還元法ではすでに流動床による反応の報告があるよう 
Table 3 Features of the reductant of silicon halide compounds for solar grade silicon production.

\begin{tabular}{|c|c|c|}
\hline Reductant & Advantages & Disadvantages \\
\hline Hydrogen & $\begin{array}{l}\text { () No solid-compound formation } \\
\text { () Easy to purify } \\
\text { () Easy to supply in gas phase }\end{array}$ & $\begin{array}{l}\times \text { Thermodynamically unfavorable reaction } \\
\times \text { Very slow reaction, low productivity } \\
\times \text { Complicated procedure for silane gases } \\
\triangle \text { Difficult to handle silane gases }\end{array}$ \\
\hline Zinc & $\begin{array}{l}\text { () No silicide formation } \\
\text { () Easy to supply in gas phase } \\
\text { ()Easy to remove the byproduct } \\
\text { OLow electrolysis voltage }\end{array}$ & $\begin{array}{l}\triangle \text { Electrolysis of } \mathrm{ZnCl}_{2} \text { is not established } \\
\triangle \text { Removal of } \mathrm{Zn} \text { from solid solution }\end{array}$ \\
\hline Aluminum & $\begin{array}{l}\text { () No silicide formation } \\
\text { ○) Easy to remove the byproduct } \\
\text { ○low electrolysis voltage }\end{array}$ & $\begin{array}{l}\times \text { Difficult to remove the unreacted } \mathrm{Al} \\
\triangle \text { Electrolysis of } \mathrm{AlCl}_{3} \text { is not established } \\
\triangle \text { Removal of } \mathrm{Al} \text { from solid solution }\end{array}$ \\
\hline Alkali/alkaline earth metal & $\begin{array}{l}\text { () Easy to supply in gas phase } \\
\text { ())Electrolysis of metal chloride is established }\end{array}$ & $\begin{array}{l}\times \text { Formation of silicides } \\
\times \text { Difficult to separate/recover product } \mathrm{Si} \\
\triangle \text { Energy consuming electrolysis }\end{array}$ \\
\hline
\end{tabular}

Table 4 Features of the solar grade silicon production processes.

\begin{tabular}{|c|c|c|}
\hline Process & Advantages & Disadvantages \\
\hline Siemens Process & $\begin{array}{l}\text { () Very high-purity silicon obtainable } \\
\text { () Resistant to contamination }\end{array}$ & $\begin{array}{l}\times \text { Batch-type process } \\
\times \text { Very slow production speed } \\
\times \text { Low energy efficiency } \\
\triangle \text { Complicated process }\end{array}$ \\
\hline Komatsu Process & $\begin{array}{l}\text { () Very high-purity silicon obtainable } \\
\text { () Resistant to contamination }\end{array}$ & $\begin{array}{l}\times \text { Batch-type process } \\
\times \text { Very slow production speed } \\
\times \text { Low energy efficiency } \\
\triangle \text { Complicated process }\end{array}$ \\
\hline Fluidized bed reaction & $\begin{array}{l}\text { () Very high-purity silicon obtainable } \\
\text { () Resistant to contamination } \\
\text { Semi-continuous process }\end{array}$ & $\begin{array}{l}\times \text { Low energy efficiency } \\
\triangle \text { Slow production speed } \\
\triangle \text { Complicated process }\end{array}$ \\
\hline $\begin{array}{l}\text { Thermal decomposition } \\
\text { or } \mathrm{H}_{2} \text { reduction of silicon halides }\end{array}$ & (O) Very high-purity silicon obtainable & $\begin{array}{l}\times \text { Batch-type process } \\
\times \text { Large amount of halogen or silicon halide produced as a byproduct } \\
\triangle \text { Slow production speed }\end{array}$ \\
\hline $\begin{array}{l}\text { Zincothermic/Aluminothermic } \\
\text { reduction }\end{array}$ & $\begin{array}{l}\text { ()High-speed reduction process } \\
\text { Semi-continuous process } \\
\text { OSimple process }\end{array}$ & $\begin{array}{l}\times \text { Sensitive to contamination } \\
\triangle \text { Removal of } \mathrm{Zn} / \mathrm{Al} \text { remaining as a solid solution }\end{array}$ \\
\hline $\begin{array}{l}\text { Reduction of silicon halides by } \\
\text { alkali/alkaline earth metal }\end{array}$ & $\begin{array}{l}\text { OHigh-speed reduction process } \\
\text { OSemi-continuous process } \\
\text { OSimple process }\end{array}$ & $\begin{array}{l}\times \text { Difficult silicon/salt separation } \\
\times \text { Difficulty in removal of alkali/alkaline earth metal remaining as inter- } \\
\text { metallic compounds } \\
\triangle \text { Sensitive to contaminations }\end{array}$ \\
\hline $\begin{array}{l}\text { Upgrading from metallurgical- } \\
\text { grade } \mathrm{Si}\end{array}$ & $\begin{array}{l}\text { () Very high productivity } \\
\text { Simple process } \\
\text { Semi-continuous process }\end{array}$ & $\begin{array}{l}\times \text { Difficult to achieve high purity } \\
\times \text { Low yield }\end{array}$ \\
\hline
\end{tabular}

に，条件によっては粉末状 $\mathrm{Si}$ の製造が可能であるため，還 元プロセスを連続法へと発展させることも原理的には可能で ある・

加えて，金属熱還元法を用いたプロセスは，現状では原料 の供給面で大きなメリットがある，金属熱還元法の主たる原 料となる $\mathrm{SiCl}_{4}$ は, Siemens 法の副生成物として安価で大量 に生産される. 半導体向けの用途には超高純度の $\mathrm{Si}$ が必要 であるため, 今後も Siemens 法あるいは類似の手法が利用 されると予想される，そのため, Siemens 法(あるいはその 類似法)の副産物である $\mathrm{SiCl}_{4}$ を, 金属級 $\mathrm{Si}$ の塩化により生 成させる $\mathrm{SiCl}_{4}$ と併用して, 金属熱還元法の原料の一部とし て利用することができる。

金属熱還元法においても, 高純度 $\mathrm{Si}$ を大量生産する場合 には, $\mathrm{Si}$ の純度管理が最も重要な要件の 1 つとなり, 八ロ ゲン化シリコンの原料だけでなく, 還元剤も同等の高純度レ ベルのものが要求される. 高純度の還元剤を確実に, しかも
長期的に安定供給するためには，チタン製錬における Kroll 法43) と同様に, 還元工程で発生する副生成物の塩を電気分 解して循環利用するクローズドサイクルを構築することが好 ましい，ケイ化物を生成しない還元剤である $\mathrm{Zn}$ と $\mathrm{Al}$ を比 べた場合, 気相で供給を行うことができる Znの方が一見有 利である.しかし，一例として以下に示すように，供給法や 反応様式を工夫すれば $\mathrm{Al}$ を還元剤として用いる場合でも効 率的な高純度 $\mathrm{Si}$ 製造が構築可能であると考えられる.

最近は, 蒸気圧が高いアルミニウムの低級塩化物の還元力 を利用して， $\mathrm{SiCl}_{4}$ を還元することで連続的に高純度 $\mathrm{Si}$ を製 造する手法も検討されている44,45). この手法は, Fig. 9 に示 す $\mathrm{Si}-\mathrm{Cl}$ 系と $\mathrm{Al}-\mathrm{Cl}$ 系の平衡ガス分圧の温度変化と, Fig. 10 に示す $1300 \mathrm{~K}$ に打ける等温化学ポテンシャル図からも わかるように, 反応系内に金属 $\mathrm{Al}$ が共存する $\mathrm{Al}-\mathrm{Si}-\mathrm{Cl}$ 系で は $\mathrm{Al}$ のサブハライド $\left(\mathrm{AlCl}_{x}, x<3\right)$ のガスが生成し，これが $\mathrm{SiCl}_{4}$ を還元して $\mathrm{Si}$ が生成することを利用している. 
(a)

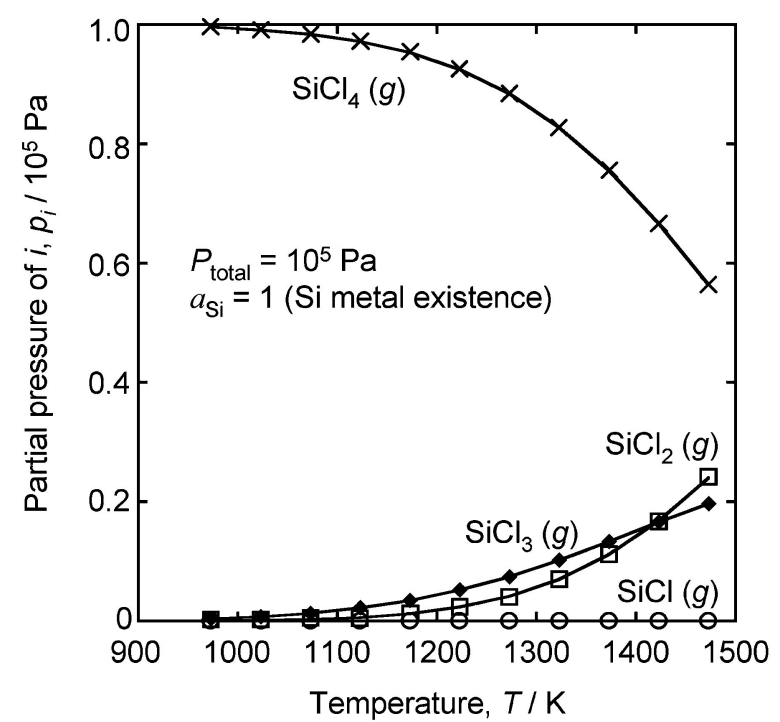

(b)

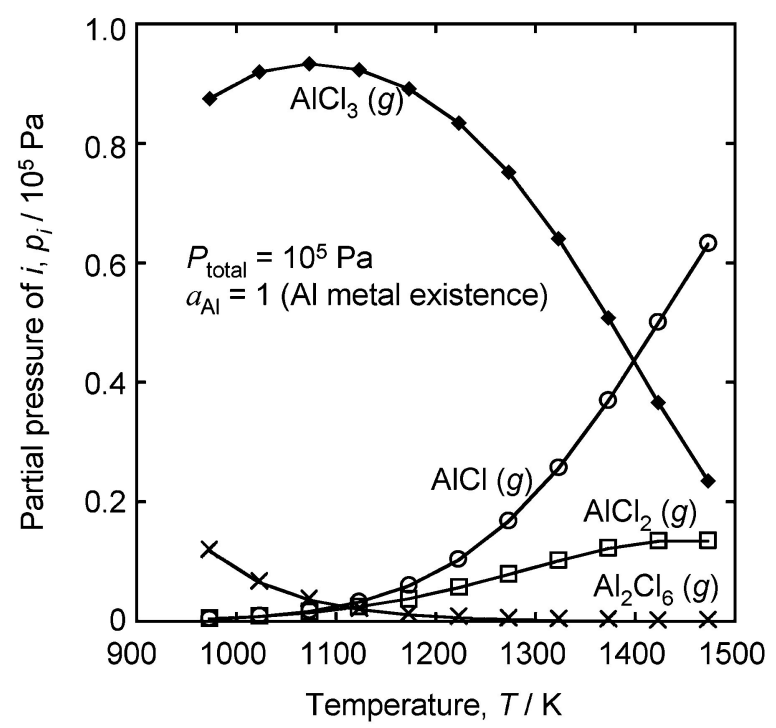

Fig. 9 Equilibrium vapor pressure of (a) Si chlorides and (b) Al chlorides ${ }^{4,45)}$. The vapor pressure is calculated under the condition that the gases equilibrate with metallic $\mathrm{Si}$ or $\mathrm{Al}$ and the total pressure of the system is $10^{5} \mathrm{~Pa}$.

(a)

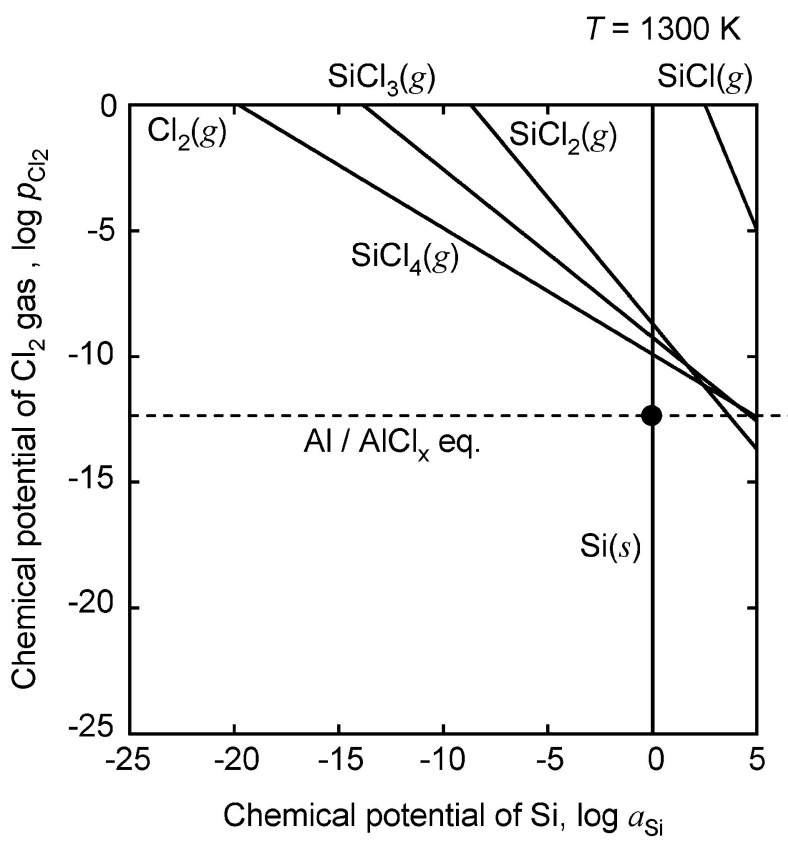

(b)

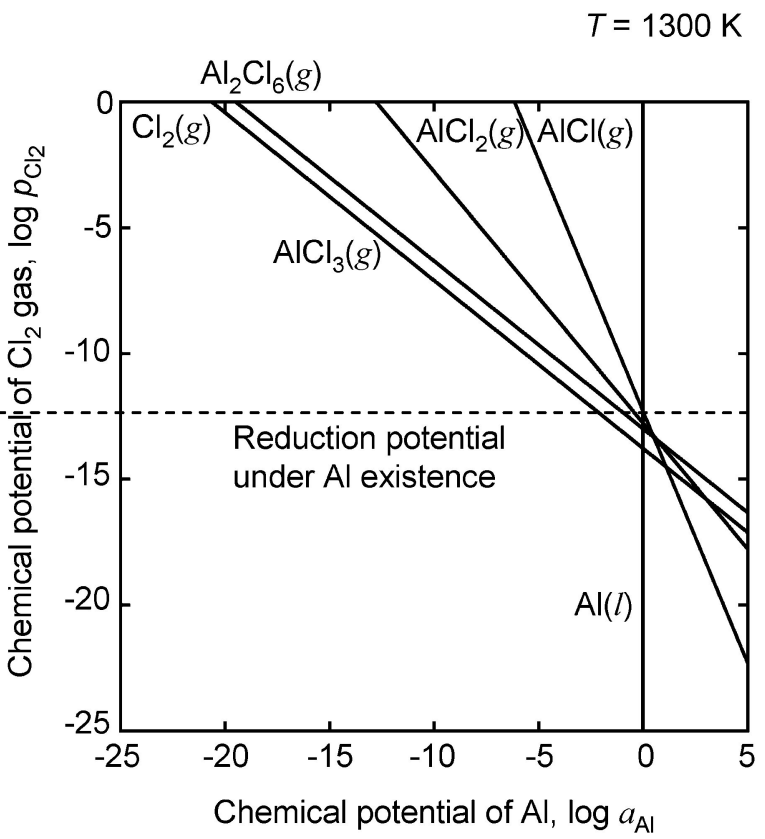

Fig. 10 Chemical potential diagram for the (a) $\mathrm{Si}-\mathrm{Cl}$ system and (b) $\mathrm{Al}-\mathrm{Cl}$ system at $1300 \mathrm{~K}^{4}$.

$$
\mathrm{SiCl}_{4}(\mathrm{~g})+\mathrm{AlCl}_{x}(\mathrm{~g}) \rightarrow \mathrm{Si}(\mathrm{s})+\mathrm{AlCl}_{3}(\mathrm{~g})
$$

上式の $\mathrm{SiCl}_{4}(\mathrm{~g})$ の還元反応では, 還元剤の $\mathrm{Al}$ サブハライド はガスで用いられ，反応に関与する物質は，生成する固体の Si 以外は全て気相となる。主な反応が気相反応であるた め, 副生成物および過㮃の還元剂から生成した Si を分離回 収するのが容易で，かつ不純物の混入を防ぐことができ，原 理的には高純度の Si が得られるという利点がある。さら に, 反応系内に $\mathrm{Al}$ を共存させる場合には, $\mathrm{Al}$ サブハライド の生成反応と $\mathrm{SiCl}_{4}$ の還元反応を含めた総括反応が金属熱還 元反応となる．このため，気相を介した連続的な金属熱還元 反応が利用でき，生産性が高いというメリットもある。
本論ではほとんど紹介できなかったが，金属級 $\mathrm{Si}(2 \mathrm{~N}$ 純 度)から不純物を直接除去して精製し, 太陽電池級の純度の $\mathrm{Si}$ を製造する手法は, 現時点の技術では収率が低く, 結果 的にコストが高くなるという欠点がある.しかし, 金属級 $\mathrm{Si}$ を治金学的な手法を用いて直接高純度化する方法は, 桁 違いに大きな生産性を有するプロセスとして発展する可能性 も有している，今後の技術革新により，スラグメタル法や偏 析・酸溶解法, 一方向凝固法などの治金学的手法をべースと した効率的な Si 精製法が開発されれば，他の太陽電池級 $\mathrm{Si}$ 製造法を圧倒して工業的な量産法に置き換わる可能性がある.

前報3)ならびに本稿で紹介した, いずれの高純度 $\mathrm{Si}$ の製 
造プロセスも，今後の技術開発動向次第で太陽電池用 $\mathrm{Si}$ の 供給を行うことのできるポテンシャルを秘めている．現時点 ではどのプロセスが次世代の太陽電池用 $\mathrm{Si}$ の製造プロセス として発展するかはわからず，これらのプロセス開発の動向 から目を離すことはできない。

\section{6. 総括}

太陽電池用 $\mathrm{Si}$ の原料の製造法として，現行の Siemens 法 に代わる，生産性の高い太陽電池級 $\mathrm{Si}$ の新製錬プロセスの 開発が現在幅広く行われている. プロセス原理上，金属熱還 元を用いた太陽電池級 $\mathrm{Si}$ の製造法は，高純度の $\mathrm{Si}$ を製造す ることが可能である.さらに，反応装置一基あたりの生産性 も Siemens 法ベースのプロセスと比較して桁違いに増大す ることが可能であり，次世代の太陽電池級 Si 製造プロセス として発展しうる可能性を有している.

太陽電池製造の先進国である日本が，近年に停滞している 理由は，原料となる太陽電池級 $\mathrm{Si}$ を需要の急増に応じて適 確に確保できなかったことが一因である，エネルギー環境分 野で重要な役割を担う太陽電池分野に抢いて，世界の主導権 を今後も日本が握るためには, 次世代の太陽電池級 $\mathrm{Si}$ 製造 法を独自に開発して，高純度 Si を低いコストで製造し，世 界に供給する必要があると考えられる。

本稿を緾めるにあたり，東京大学生産技術研究所森田一樹 教授, ならびに，住友化学株式会社三枝邦夫博士の各氏に貴 重な助言や情報をいただいた。記して謝意を表す。

\section{文献}

1) H. Schweickert, K. Reuschel and H. Gutsche: U.S. Patent 3,011,877 (1961)

2) H. Gutsche: U.S. Patent 3,042,494(1962).

3) K. Yasuda, K. Morita and T. H. Okabe: J. MMIJ, accepted, (2009).

4) I. Barin: Thermochemical Data of Pure Substances, (VCH Verlagsgesellschaft, Weinheim, 1995).

5) D. W. Lyon, C. M. Olson and E. D. Lewis: J. Electrochem. Soc. 96 (1949) 359-363.

6) L. Bertrand: U.S. Patent 3,012,862 (1961).

7) K. H. Butler and C. Marcus: U. S. Patent 2,773,745(1956).

8) C. M. Olson: U. S. Patent 2,804,377 and 2,805,133(1957).

9) E. R. Johnson and J. A. Amick: J. Appl. Phys. 25 (1954) 12041205.

10) T. Ishino and A. Matsumoto: Kogyo Kagaku Zasshi 68(1965) 265-268.
11) J. M. Blocher Jr., M. F. Browning and D. A. Seifert: DOE/JPL Report 954339-81/21(1981).

12) D. A. Seifert and M. F. Browning: AIChE Symposium Series 78 (1982) 104-115.

13) Y. Natsume, K. Kaneko and T. Ogasawara: Japanese Patent, Toku Kai H11-92130 (1999).

14) T. Shimamune and I. Yoshikawa: Japanese Patent, Toku Kai H15-342016 (2003)

15) E. Robert and T. Zijlema: PCT International Patent WO2006/ 100114(2006).

16) S. Honda, M. Yasueda, S. Hayashida and M. Yamaguchi: Japanese Patent, Toku Kai H19-145663 (2007).

17) S. Sakaguchi: PCT International Patent WO2007/119605 (2007).

18) V. M. Weaver: U.S. Patent $1,238,604(1917)$

19) S. Yoshizawa, T. Hatano and S. Sakaguchi: Kogyo Kagaku Zasshi 64(1961) 1347-1350.

20) J. C. Terry, A. Lippman, R. F. Sebenik and H. G. Harris: Canadian Patent 1,003,223(1977).

21) P. Woditsch, M. Abels and B. Brazel: U.S. Patent 4,525,334 (1985).

22) K. Saegusa and T. Yamabayashi: PCT International Patent WO2007/001093(2007).

23) T. B. Massalski, H. Okamoto, P. R. Subramanian and L. Kacprzak, eds.: Binary Alloy Phase Diagrams, 2nd Edition, (ASM International, Metals Park, Ohio, USA, 1990).

24) Nihon Keizai Shimbun, Article on May 28, 2008.

25) T. Yoshikawa and K. Morita: Sci. Technol. Adv. Mater. 4 (2003) 531-537.

26) K. Morita and T. Yoshikawa: Materia Japan 46(2007) 133-136.

27) K. Morita, T. H. Okabe and M. Maeda: J. JFS 80 (2008) 375379

28) J. R. Davis Jr., A. Rohatgi, R. H. Hopkins, P. D. Blais, P. RaiChoudhury, J. R. McCormick and H.C. Mollenkopf: IEEE Trans. Electron Devices ED-27 (1980) 677-687.

29) N. Yuge, M. Abe, K. Hanazawa, H. Baba, N. Nakamura, Y. Kato, Y. Sakaguchi, S. Hiwasa and F. Aratani: Prog. Photovolt. Res. Appl. 9(2001) 203-209.

30) N. Yuge, K. Hanazawa, S. Hiwasa and Y. Kato: J. Japan Inst. Metals 67 (2003) 575-582.

31) A. C. Vournasos: Z. Anorg. Chem. 81(1913) 364-368.

32) R. S. Aries: U.S. Patent 3,041,145(1962).

33) B. Kamenar and D. Grdenic: Z. Anorg Allg. Chem. 321 (1963) 113-119.

34) M. G. Fey, F. J. Harvey and J. McDonald: U.S. Patent 4,102,765(1978)

35) R. A. Frosch and A. R. Keeton: U.S. Patent 4,169,129(1979).

36) R. A. Frosch, C. B. Wolf and T. N. Meyer: U.S. Patent $4,188,368$ (1980).

37) J. Eringer: U.S. Patent 2,172,969(1939).

38) A. Sanjurjo, L. Nanis, K. Sancier, R. Bartlett and V. Kapur: J. Electrochem. Soc. 128(1981) 179-184.

39) A. Sanjurjo: PCT International Patent WO1983/002443(1983).

40) F. A. Schmidt, D. Rehbein and P. Chiotti: U.S. Patent 4,446,120 (1984).

41) N. Auner: PCT International Patent WO2003/059814(2003).

42) T. Watanabe, eds., Encyclopedia of the Elements, (Asakura Publications, Tokyo, 2007).

43) W. J. Kroll: Trans. Am. Electrochem. Soc. 78(1940) 35-47.

44) T. H. Okabe and K. Saegusa: Japanese Patent, Toku Kai H21091228(2009).

45) K. Yasuda, K. Saegusa and T. H. Okabe: Mater. Trans. 50 (2009) 2873-2878. 